\title{
GLL
}

Geomatics, Landmanagement and Landscape No. 4 • 2019, 183-199

\section{ANALYSIS OF THE DEVELOPMENT OF LUBLIN CITY BIKE STATIONS VERSUS THE ECONOMIC AND SPATIAL CONDITIONS IN THAT CITY}

\author{
Krzysztof Gawroński, Karol Król, Grażyna Gawrońska, Bartosz Kubicki
}

\begin{abstract}
Summary
The analysis covered the city bike rental system in Lublin and the development of the so-called Lublin City Bike (LRM) network. The LRM network was chosen due to its dynamic development, because Lublin has the most city bikes per capita in Poland. LRM was launched in June 2014. Since then, the Lublin City Bike consists of 951 bikes located in 97 rental stations in Lublin and Świdnik. The purpose of the present work is to analyse the development of city bike docking stations in Lublin against the background of economic and spatial conditions of the city. The analyses were performed using GIS software. The greatest interest in LRM was recorded in the central part of the city. It has been shown that the development of cycling infrastructure does not have a significant impact on the spatial coverage of Lublin City Bike. Developments planned until 2022 will also not significantly affect the extension of LRM coverage, as they are focused on increasing the density of stations. Furthermore, the location of the LRM stations is not related to the population density in individual city districts.
\end{abstract}

\section{Keywords}

city bike $\bullet$ city bike docking stations $\bullet$ public transport $\bullet$ spatial analysis $\bullet$ cartographic visualization

\section{Introduction}

When planning spatial development of cities, local government authorities are increasingly paying attention to such values of space that will facilitate and promote sports and recreational activity. To a large extent, this is due to the growing interest in an active lifestyle [Kwon et al. 2015]. One of the manifestations of this phenomenon is the increase in activities related to the use of bicycles, and the development of cycling tourism. In many cities, bicycle infrastructure in the form of bicycle paths, technical components that accompany them, and bicycle rental networks are developing dynamically. Bicycle paths are marked out in rural areas, such as the Green Velo East Bicycle Trail [Wilczyński 2018]. 
According to statistics, a cycling trip can save an average of fifteen minutes. The main reason for this is the lack of waiting time, which is typical e.g. for a bus or tram, as well as the lack of transfers [European Commission 2000]. In addition, bicycle transport is largely independent of traffic restrictions such as road congestion (so-called "traffic jams") or road repairs. It is worth noting that the congestion of public roads affects the loss of Gross Domestic Product (GDP). According to the report from the European Commission Green Paper [1996], congestion in roads causes a decline in GDP of EU countries by up to 2\%. The value of losses is estimated at EUR 120 billion, which is four times the expenditure incurred by EU countries on public transport. Research in London has shown that traffic jams in the city cause a loss of around 10 billion EUR a year [European Commission 2000]. Furthermore, the distances covered by car in the city usually do not exceed $5 \mathrm{~km}$. Meanwhile, by bike you can travel the distance of $4 \mathrm{~km}$ in merely 15 minutes [Kopta et al. 2012].

The advantages of cycling include, among others: speed and comfort (cycling directly from one place to another, avoiding crowded places, using shortcuts and roads that are inaccessible to cars), relatively low maintenance costs, health and safety benefits (traffic cycling is a minimal threat to other road users, it does not pollute the air, does not cause noise etc.) [Wiącek and Gorczyca 2013]. It is also worth noting that on the surface, which corresponds to one parking space for a car, about 10 bicycles can be fitted. In addition, a person riding a bicycle takes 8 times less space than a passenger car [Wienik and Gorczyca 2013].

According to the European Commission [2000], enterprises are increasingly willing to promote the use of bicycles as a means of commuting among their employees. Savings are obtained by abandoning the construction of parking lots, and reducing the sickness-related absence of employees. According to CROW [1993], the substantial impact on the development of bicycle traffic in the city involves: total coherence of sources and goals covered by bicycle infrastructure, directness (minimizing detours, elongation factor, and delay factor), as well as safety and comfort. The location of bicycle rental facilities in the city also to some extent affects its acoustic climate and air protection.

The purpose of the present work is a spatial analysis of the correlations observed between the Lublin City Bike stations and the city's cycling infrastructure versus population density, distribution of public transport, recreational and leisure areas, as well as areas of economic and educational importance in the city.

\section{Biking infrastructure}

Socio-economic development is associated with an increase in investment, employment, and production value, as well as the development of technical and social infrastructure. In addition, it is conditional on human capital and depends on geographical location [Król and Prus 2018, Prus et al. 2018].

Bicycle infrastructure includes every element related to cycling. Development of urban biking infrastructure and organization of cyclist traffic should be based, among 
other things, on guidelines developed by the Dutch organization CROW (Centre for Research and Contract Standardization in Civil and Traffic Engineering) [Hyły and Kopta 2010]. These guidelines include: (1) consistency - everywhere should have bicycle access, (2) directness - minimum detours and elongation factor, (3) convenience - minimization of cyclist's physical effort and delay factor, (4) safety - minimization of overlap points with pedestrian, car and other traffic, (5) attractiveness - the bicycle system should be user-friendly and meet the needs of its users [CROW 1993]. The principle is adopted that if one of the requirements is not met, the bicycle infrastructure design should be improved. However, due to local conditions and legal regulations currently in force in Poland, the requirements set by the CROW organization should not be treated as absolute, but as an inspiration for bicycle infrastructure projects and a list of good practices.

The most important legal provisions regarding cycling infrastructure in Poland include: The Road Traffic Convention drawn up in Vienna, technical and design standards developed in city and municipal offices as part of the planning and development of cycling infrastructure, and selected legal acts [Act 1997, Regulation 1999, Regulation 2002, Regulation 2003].

Bicycle paths are the main element of a bicycle route, and hence also of the biking infrastructure. There are many types of bicycle paths. The so-called bicycle lanes, which are not costly to create, are very common. A bicycle lane is a part of the road separated by a white line (usually a continuous line), intended for one-way bicycle traffic, in line with the general traffic direction on a given street. The bicycle lane width should be 1.5 meters [Cal 2015]. A specific variation of the bike lane is the counter-lane. Counterlanes for cyclists are used on one-way streets. Bicycle traffic takes place in the opposite direction to the direction of other vehicles [Rowerowy Szczecin 2012]. Another example of adapting the streets to riding bicycles against the main flow of traffic is the counter-traffic. Bicycle counter-traffic is used on one-way streets with no entry (roadsign type B-2). However, this restriction does not apply to bicycles, which is indicated by the road-sign T-22 "does not apply to bicycles". In addition, the T-22 road-sign is used when cycling is allowed, e.g. on a pedestrian walkway.

The most commonly used type of bicycle path is a combined path for bicycles and pedestrians, i.e. pedestrian-bicycle path. This type of path is marked with the compound road-sign C-13 and C-16. There are two types of pedestrian-bicycle paths. The first is marked with the compound road-sign C-13 and C-16, on which pedestrians are separated from the bike by a horizontal line. This road-sign is applied when the volume of pedestrian traffic is low, and there are no separate paths for bicycles and pedestrians. When the vertical line separates the pedestrian sign from the bicycle, it is divided into two independent lanes - one for pedestrians, and the other, for cyclists [Cal 2015]. In turn, the C-13 sign is used on independent bicycle routes, where there is a clear separation of the bicycle route from other traffic lanes [Brzeziński et al. 2009b]. In addition, cyclist-friendly streets and traffic calming zones can be distinguished. Traffic calming zones, i.e. bicycle-friendly streets, are residential areas typically with single-family housing. Also, they are often encountered in historic areas [Cal 2015]. 
In traffic calming zones, pedestrians, bicycles and cars may travel together at a speed of $30 \mathrm{~km} / \mathrm{h}$. Cyclist-friendly streets are divided into two types: (1) those adapted to the joint traffic of cyclists and motor vehicles and (2) those adapted to the common movement of pedestrians, cyclists and motor vehicles. In both cases, various technical measures are used to ensure compliance with speed limits, while in the second case, additional measures are used to limit car traffic [Brzeziński et al. 2009b]. The last example of bicycle paths is the combined bus-bicycle lane. This is part of the road with a designated bus lane, which cyclists can also use [Cal 2015].

An example of bicycle infrastructure accompanying bicycle routes is a "lock" for bicycles. It is a part designated along the entire width of the road or lane at the inlet of the intersection, intended for stopping bicycles, for instance at traffic lights, in order to change direction or give way. In addition, bicycle through-passes are a helpful element of cycling infrastructure, i.e. a common part of a bicycle road and the road or track crossing it, distinguished by a special marking. Bicycle through-passes are connected with pedestrian crossings. In the case of bicycle paths, bicycle roundabouts are also used [Hyły and Kopta 2010]. Bicycle infrastructure also includes: bicycle parking lots, bicycle stands, "bicycle sergeant" (sign P-27), bicycle racks, traffic lights, guides and ramps on stairs, bicycle storage rooms, and integration nodes (Bike \& Ride or B\&R, park your bike and ride public transport) [Rowerowy Szczecin 2012].

\section{System of bike docking stations}

The bicycle docking station system also referred to as the public bicycle system or city bike system can be defined as a means of transport carried out by means of bicycles available at rental stops [Brzeziński et al. 2009]. The beginnings of the cycling system date back to 1965, when in Amsterdam, the Netherlands, the Provos organization implemented the White Bike Plan [Shaheen et al. 2010]. The idea of this undertaking was to provide fifty bicycles to the city residents free of charge, which were painted white and left throughout the city. However, they were not secured, and most of them were stolen or destroyed. Currently, city bike systems can be found in many larger cities, where cycling is developing dynamically and is used not only for recreational but also transportation purposes. Shaheen et al. [2010] listed the benefits of a public bicycle network, including health and environmental, increasing the city's accessibility, and strengthening the public transport network.

Public (city) bicycle rental systems can be divided into four basic types [Brzeziński et al. 2009a]:

1) traditional - consist of a network of several rental shops served by staff, usually with within specified, limited opening hours;

2) automated with bicycle docking points - a system of self-service bicycle stations, equipped with a digital panel enabling the collection and return of the bike, access to information about the system, registration in the system, and making payments; 
3) not-automated with bicycle docking points - a system of self-service bicycle stations equipped with a digital panel enabling the collection and return of a bike, however in this case the bikes are rented and returned for a deposit;

4) automated without bicycle docking points - the bikes are equipped with a locking and locating mechanism (GPS receiver) and can be left anywhere in a particular city zone.

There are many companies throughout the world specialized in cycling systems. In 2015, the number of bicycles in public bicycle systems in all world was around $1,270,000$ (including $1,036,400$ bicycles in China). The increase recorded relative to 2014 was about 324,000 units. In 2015, there were 1005 locations (cities, municipalities, districts) in the world with a bicycle rental system [Meddin 2016]. In 2015, there were 17 public bike systems in Poland.

\section{Lublin City Bike (Lubelski Rower Miejski, LRM)}

The LRM system was launched in June 2014. The cycling season in Lublin ended in 2014 on November 30. Bicycles from the LRM network in 2014 were used 128,644 times [LRM 2016]. However, this number also includes "fictitious" rentals, that is, situations where the bike was picked up and returned to the same station after a short time, and the duration of the rental was not more than 2 minutes. It is believed that this type of loan were simply attempts made by new system users to learn about the specifics of its operation. The number of rentals lasting more than 2 minutes was 103,652 [Kubicki 2015].

The 2015 cycling season lasted in Lublin from March 20, 2015 to the end of November. The number of loans was 436,965 [LRM 2016]. During this season, the City Bike System was extended, by including 3 sponsored stations. The latter were created at the three largest shopping malls in Lublin. In 2016, the LRM system was expanded by another 47 stations, including 42 stations ( 2 intended for children over 6 years) in Lublin itself, and 5 in the nearby city of Swidnik. Stations in both cities are integrated with each other. It is worth mentioning that 5 stations were financed from the funds of the citizens' budget of the city of Lublin [LRM 2016]. The expansion of the city bike system meant that the availability of LRM bikes for residents increased - in 2015 there was one LRM bike per 799 inhabitants, and already in 2016, one bike per 404 inhabitants. The Lublin City Bike is currently one of the rental systems in Poland with the largest number of available bikes per inhabitant [Kubicki 2015].

The LRM system in 2016 consisted of 891 bicycles, including: 826 "ordinary" bicycles, 4 tandems and 20 bicycles for children, located in Lublin, plus 41 bicycles located in Świdnik. LRM also consists of 90 stations, of which 5 are located in Świdnik and 85 stations are located in Lublin [LRM 2016]. In 2019, Lublin City Bike comprises 951 bikes located at 97 rental stations in Lublin and Świdnik. A standard LRM station consists of 15 units - places for leaving or renting a bike, and 5 units (bicycle stands) for private bikes (Photo 1). The system assumes that there should be 10 bikes at each station. The length of the bicycle path network in Lublin is about $125.18 \mathrm{~km}$, including $105.51 \mathrm{~km}$ of independent bicycle paths and $19.67 \mathrm{~km}$ of bike lanes running along with the street. 


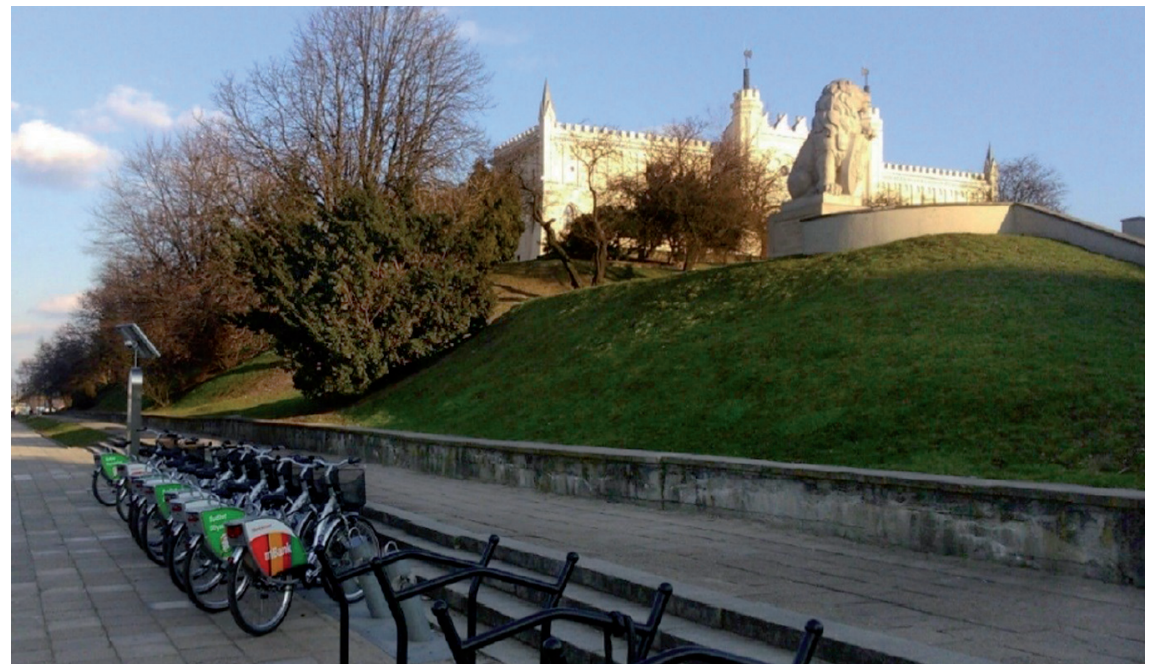

Photo: B. Kubicki

Photo 1. Bike docking station No. 6909 (al. Tysiąclecia, Plac Zamkowy)

\section{Material and methods}

Lublin is located in the eastern part of Poland in the Lublin region/voivodeship (Fig. 1). It is located on the northern edge of the Lublin Upland, which is built of Cretaceous formations. The city lies in the basin of the Bystrzyca river, with two other rivers feeding into it: Czechówka and Czerniejówka [Gawarecki 1976]. The Bystrzyca river divides Lublin into two parts in terms of landscape: the left bank (varied terrain - valleys, loess gullies) and the right bank (flat areas).

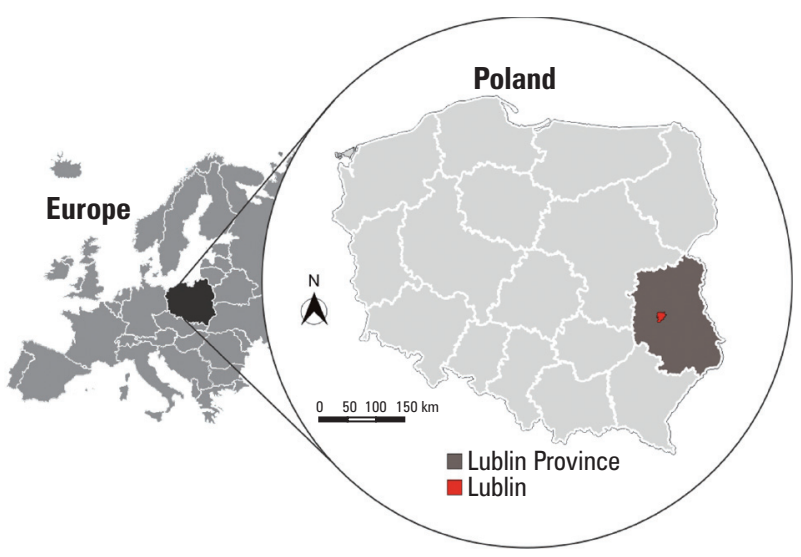

Source: Authors' own study

Fig. 1. Location of Lublin in Poland 
The city is the largest economic, academic and cultural centre east of the Vistula (Wisła) river. Its particular advantage is the short distance from the eastern border with Ukraine (the nearest border crossing is about $100 \mathrm{~km}$ from the city limits) and Lublin Airport, allowing access to major cities and transport hubs in Europe.

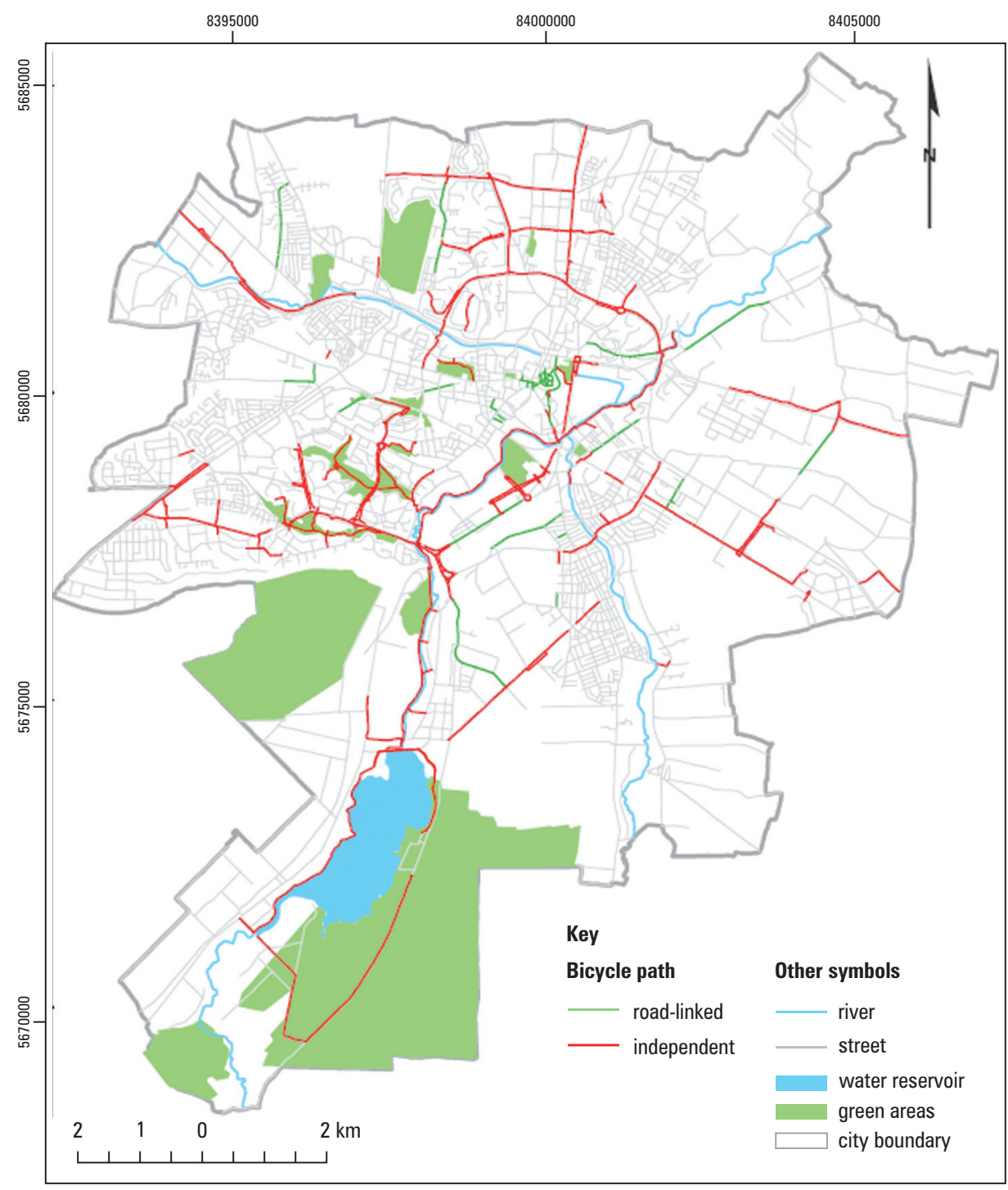

Source: Authors' own study

Fig. 2. Map of the existing biking infrastructure in Lublin (scale 1:90 000) 
The analysis covered city bike rental scheme in Lublin, i.e. Lublin City Bike system (LRM). The city bike network in Lublin was chosen due to its dynamic development - Lublin has the most city bikes per capita in Poland. In its Resolution [2011], the City Council of Lublin defined the City Bike System as a network of self-service bike rentals in the city, organized in a way that allows picking and returning the bike in each of them. The Lublin City Bike was launched on September 19, 2014 and numbered 400 bikes and 40 stations (Fig. 2).

The analysis of the development of Lublin's cycling infrastructure was carried out subdivided into four time periods. The first two periods fall in 2015 and 2016, and they relate to statistics on the current use of the Lublin City Bike. In turn, the subsequent two periods present the development of cycling infrastructure in Lublin - until 2018 and until 2022. In addition, the study poses a number of research questions:

1. What impact does the development of the Lublin City Bike and the bicycle path network have on the system's coverage within the city?

2. Does the number of Lublin City Bike stations correspond to the population density of Lublin?

3. Does the public transport network impact the popularity of the Lublin City Bike stations?

4. Is there a spatial relationship between the recreational and leisure areas, and the popularity of the Lublin City Bike stations?

5. What impact do areas of economic importance have on the popularity of the Lublin City Bike?

Statistics on the use of LRM bicycles in 2014-2015 were obtained from the network operator, i.e. the company Nextike Polska Sp. z o.o. limited company. Data collected from the geoportal of the city of Lublin as well as formal and legal documents regarding the development of cycling infrastructure in Lublin were also used (Table 1).

Table 1. Data sources

\begin{tabular}{|l|l|}
\hline \multicolumn{1}{|c|}{ Data source } & \multicolumn{1}{|c|}{ Statistical data } \\
\hline $\begin{array}{l}\text { Nextbike Polska Sp. z o.o. (limited } \\
\text { company) }\end{array}$ & $\begin{array}{l}\text { Data od the number of rentals and returns in Lublin in } \\
\text { the period of September through November }\end{array}$ \\
\hline Lublin City Bike website & $\begin{array}{l}\text { Information on the number of docking stations, number } \\
\text { of bikes and their types, as well as statistical data from the } \\
\text { years 2014-2015 }\end{array}$ \\
\hline $\begin{array}{l}\text { Demographics yearbook 2015, Lublin. } \\
\text { eu website }\end{array}$ & $\begin{array}{l}\text { Demographics (including population/number of } \\
\text { inhabitants), economic data (including number of } \\
\text { businesses), city area }\end{array}$ \\
\hline $\begin{array}{l}\text { Spatial Information System of the } \\
\text { Municipal Transport Authority in Lublin }\end{array}$ & Information on Lublin's public transport \\
\hline
\end{tabular}




\begin{tabular}{|l|l|}
\hline $\begin{array}{l}\text { Resolution Nr 553/XXIII/2012 of Lublin } \\
\text { City Council of 6 September 2012 }\end{array}$ & Data on population numbers in various districts of Lublin \\
\hline & \multicolumn{1}{|c|}{ Spatial data } \\
\hline $\begin{array}{l}\text { City Geoportal - Spatial Information } \\
\text { System of Lublin city }\end{array}$ & $\begin{array}{l}\text { Data made available via the WFS service: city boundaries, } \\
\text { district borders, land use, buildings, water reservoirs, } \\
\text { paid parking zones, business zones, streets, rivers, bicycle } \\
\text { lanes/paths, LRM stations, bus stops }\end{array}$ \\
\hline $\begin{array}{l}\text { 'Map of biking infrastructure of Lublin } \\
\text { and surroundings' website }\end{array}$ & $\begin{array}{l}\text { Data obtained via vectorization - polylines of the existing } \\
\text { and planned segments of bike paths }\end{array}$ \\
\hline $\begin{array}{l}\text { Strategy for the implementation } \\
\text { of bike path system in Lublin with } \\
\text { environmental impact assessment }\end{array}$ & $\begin{array}{l}\text { Data obtained via vectorization of the annexes to the } \\
\text { report }\end{array}$ \\
\hline
\end{tabular}

Source: Authors' own study

Geoinformation plays an increasingly important role in the sales of tourist products [Król 2015a, Król 2015b, Król and Bedla 2016]. Spatial analyses and visualizations of the results were made with the help of GIS software applications, including: ArcGIS 10.4, ArcMap 10.4, ArcCatalog 10.4, QGIS Desktop 2.14.0 and MapViewer 7. The results of the analyses were presented on maps on a scale of 1:90,000, made in the coordinate system 2000 (zone 8).

\section{Results and inferences}

In order to determine the coverage of the Lublin City Bike stations, a network analysis was used, i.e. a coverage analysis. It was assumed that LRM stations have the coverage in the range of $625 \mathrm{~m}, 1250 \mathrm{~m}, 1875 \mathrm{~m}$ and $2500 \mathrm{~m}$, which corresponds to the coverage expressed in a unit of time, i.e. 5, 10, 15 and 20 minutes. In 2016, the range of the Lublin City Bike station covered 55\% of the city's area. Detailed data on the area within the LRM coverage is presented in Table 2.

Table 2. Coverage of the Lublin City Back system docking stations in 2015-2022

\begin{tabular}{|c|c|c|c|c|c|}
\hline \multirow{2}{*}{ Year } & \multicolumn{5}{|c|}{ Coverage of the LRM stations according to access time } \\
\cline { 2 - 6 } & up to 5 minutes & $\mathbf{5 - 1 0}$ min & $\mathbf{1 0 - 1 5}$ min & $\mathbf{1 5 - 2 0}$ min & Total \\
\hline 2015 & $11 \%$ & $19 \%$ & $13 \%$ & $9 \%$ & $52 \%$ \\
\hline 2016 & $21 \%$ & $20 \%$ & $8 \%$ & $7 \%$ & $56 \%$ \\
\hline 2018 & $21 \%$ & $20 \%$ & $8 \%$ & $7 \%$ & $56 \%$ \\
\hline 2022 & $22 \%$ & $22 \%$ & $9 \%$ & $8 \%$ & $61 \%$ \\
\hline
\end{tabular}

Source: Authors' own study 
The greatest impact on the coverage of municipal bike stations is the increase in their number within the city. The density of the LRM station would reduce the travel time "from station to station" down to 5 minutes (Fig. 3). The development of the bicycle infrastructure has no significant impact on the coverage of the Lublin City Bike. It only affects the comfort of riding, and creating bicycle paths in places inaccessible to cars.

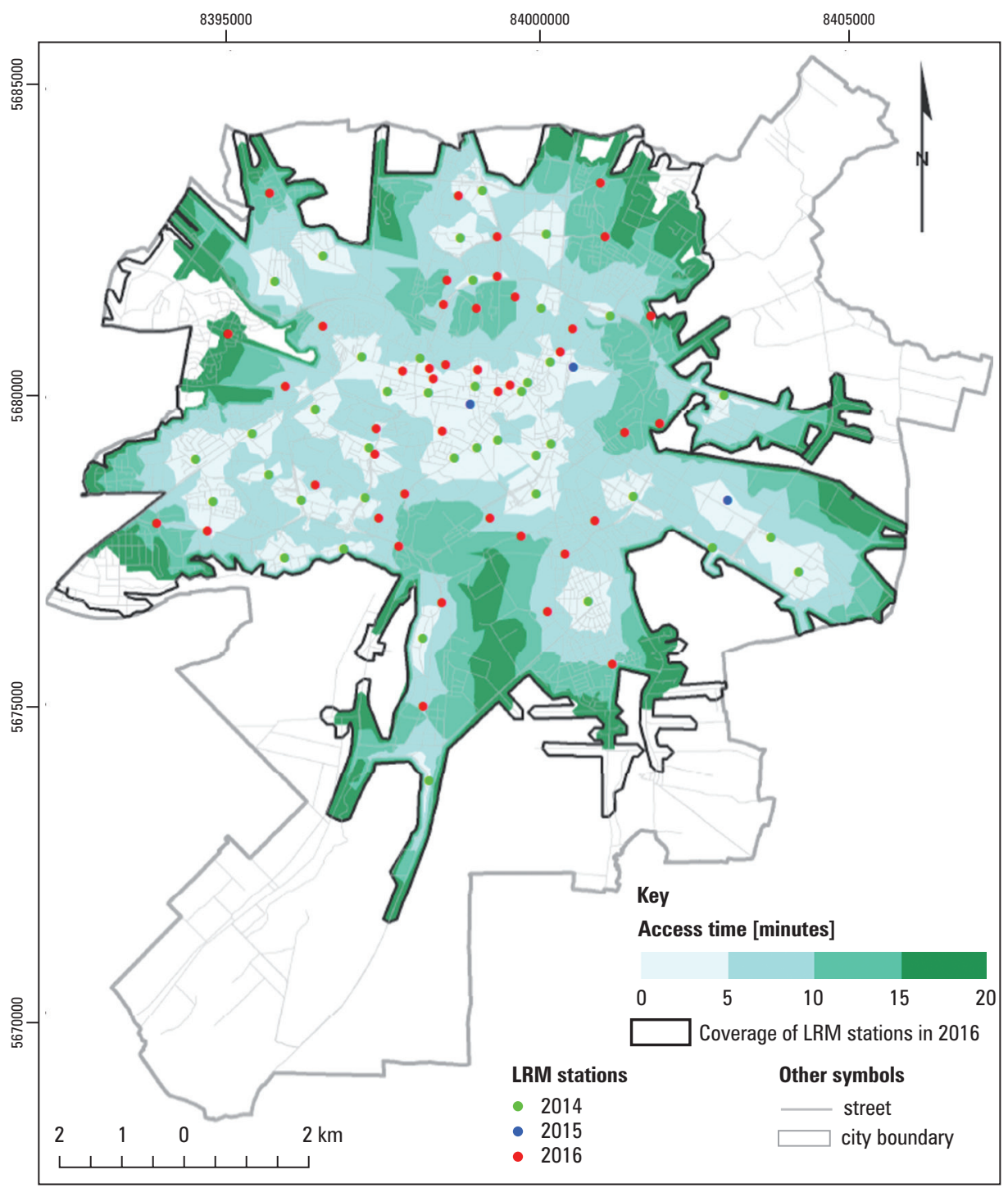

Source: Authors' own study

Fig. 3. Coverage of the Lublin City Bike system in 2016 (scale 1:90 000) 
By 2022, investments are planned in new LRM stations and the development of the bicycle path network (Fig. 4). However, these investments will not significantly increase the spatial coverage of the LRM, as they are focused on increasing the density of the docking stations. The effect of the investment will therefore be a reduction in travel time between stations, which may lead to an increased use of the LRM. At the same time, however, by 2022, few new areas will also be covered by the LRM system.

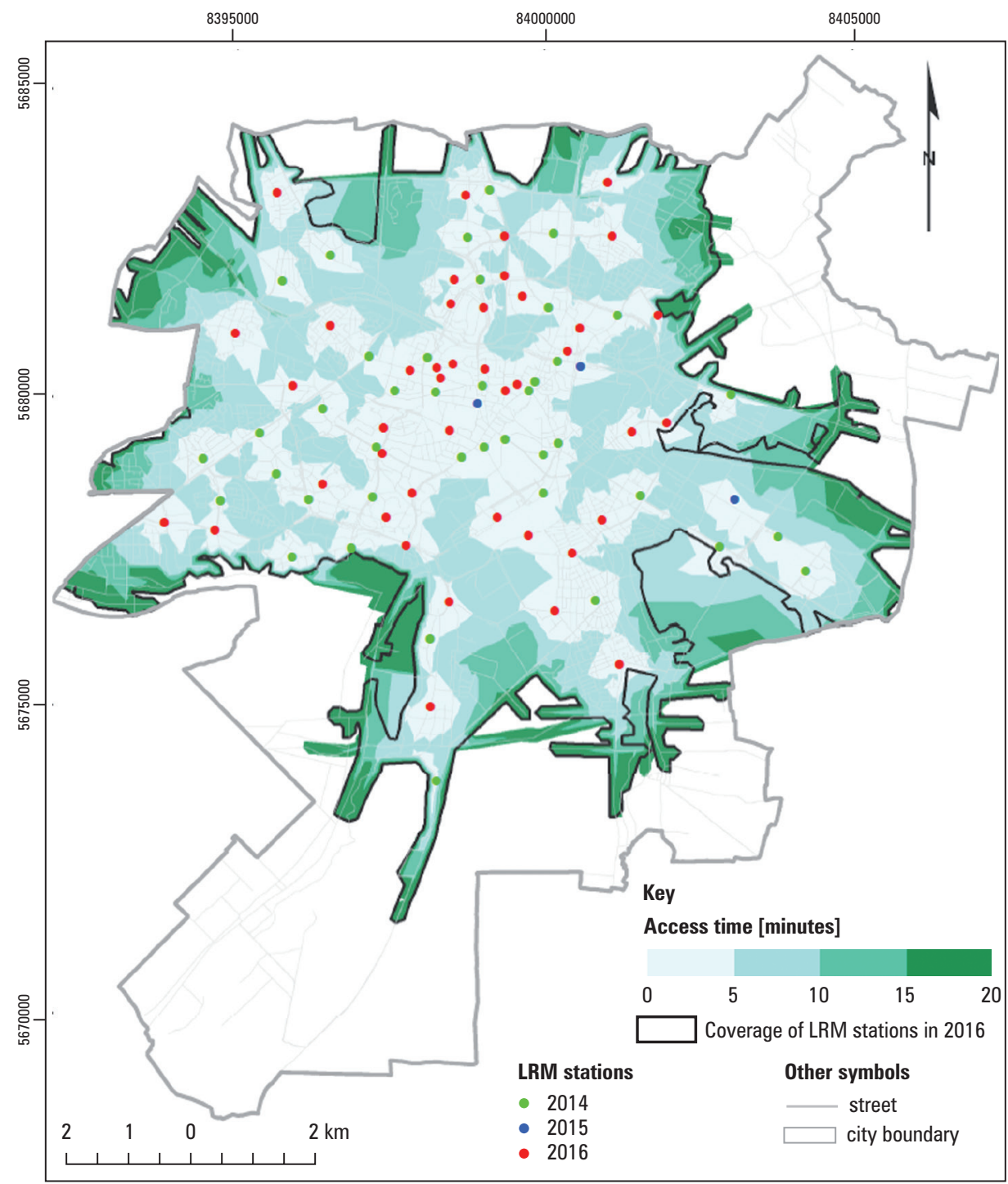

Source: Authors' own study

Fig. 4. Projected coverage of the Lublin City Bike by 2022 (scale 1:90 000) 
Analyses conducted with the use of the SQL language allowed us to answer the question whether the number of Lublin City Bike stations corresponds to the population density of Lublin. This was made possible by assigning to respective areas (districts) the number of inhabitants and the number of city bike docking stations. Dorling's amorphous cartodiagram was used to present the results [Faliszewska and Korycka-Skorupa 2010]. In the Dorling cartogram, the number of bicycle stations per district is shown by the size of the basic fields (circles), while the colour intensity reflects the population density (Fig. 5).

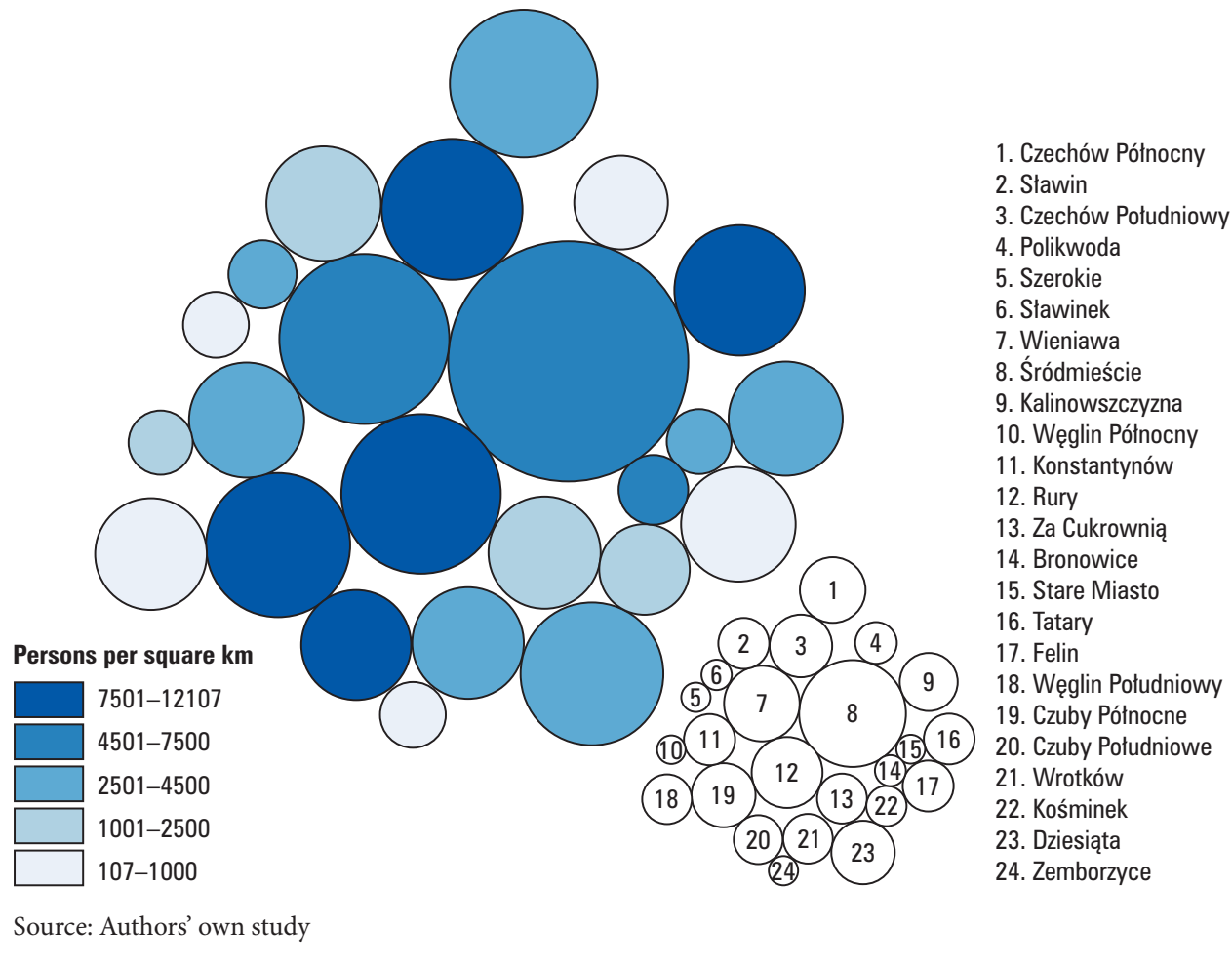

Fig. 5. Dorling anamorphic cartogram for the year 2016

Based on the analyses, it can be concluded that the location of the Lublin City Bike stations is not related to the population density in individual city districts. The largest number of stations was recorded in the Sródmieście district, despite the fact that the population density is not the highest there, remaining in the range from 4501 to 7500 people per $\mathrm{km}^{2}$. The new LRM stations commissioned in 2016 covered three additional districts - Ponikwoda, Szerokie, and Sławinek. This investment also increased the number of stations in districts with a large population (ranging from 7501 to 12107 people per $\mathrm{km}^{2}$ ).

The greatest interest in LRM was recorded in the central part of the city, in particular in the Wieniawa and Śródmieście districts (Fig. 6). In Śródmieście and Czechów 
Południowy, the decline in popularity of city bikes has been observed, which may be due to the lower density of stations in these districts. The increase in popularity of LRM is also noticeable in the Za Cukrownią district. The least interest in a city bike in 2015 was recorded in the Sławin, Felin and Zemborzyce districts. These areas are the furthest in relation to the central part of the city, which can cause such low popularity of the LRM there. The expansion of the network, which was carried out in 2016, covered primarily the central part of the city.

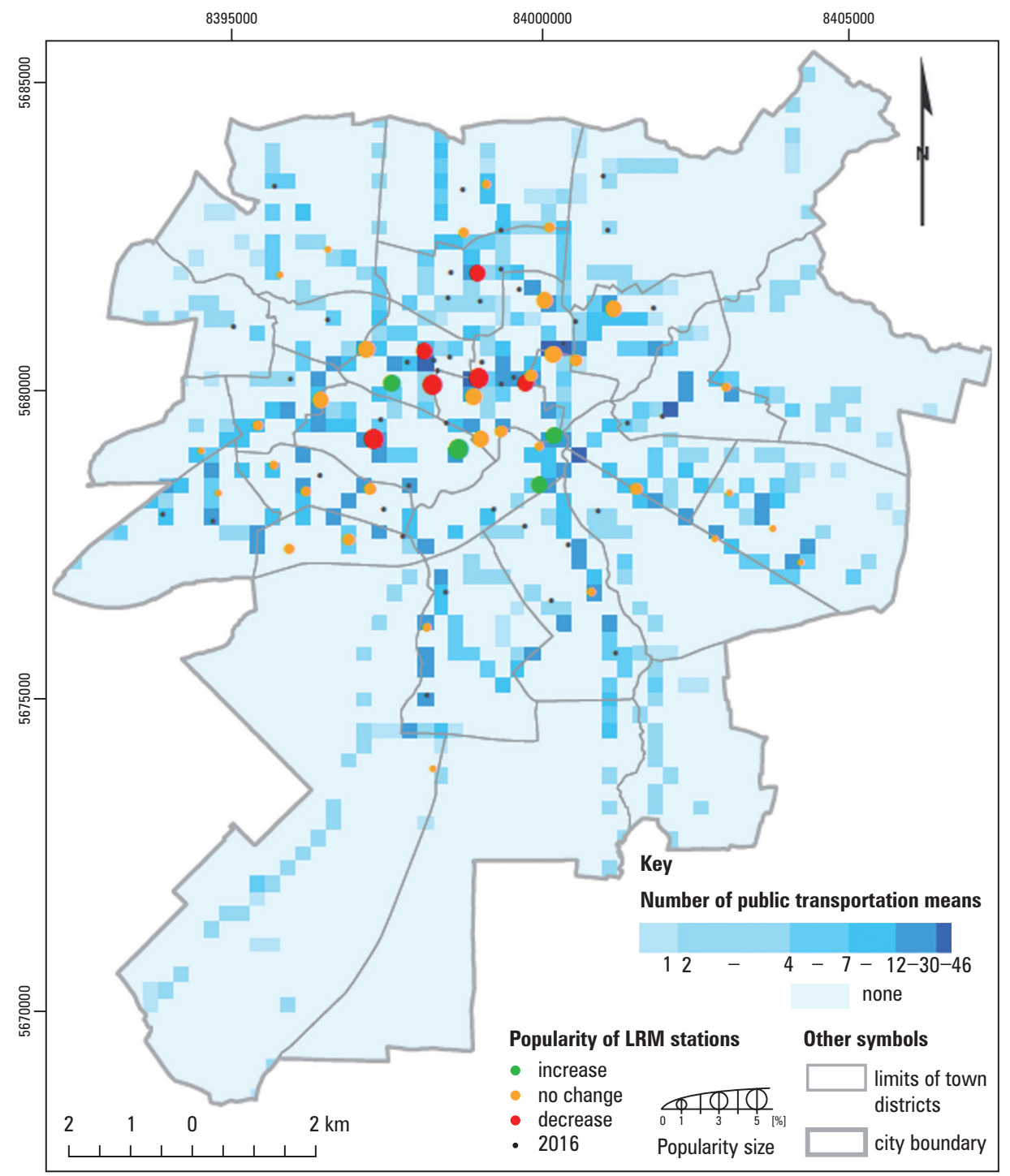

Source: Authors' own study

Fig. 6. Popularity of the LRM versus public transport (scale 1:90 000) 
Only 6 stations increased the total coverage of the city bike system in the north and east-south directions. Many stations were created in-between the existing ones, thus compacting the network and increasing its complexity. LRM stations have also been very popular in areas where there are a large number of bus lines. To some extent, this is due to the location of new stations in these places.

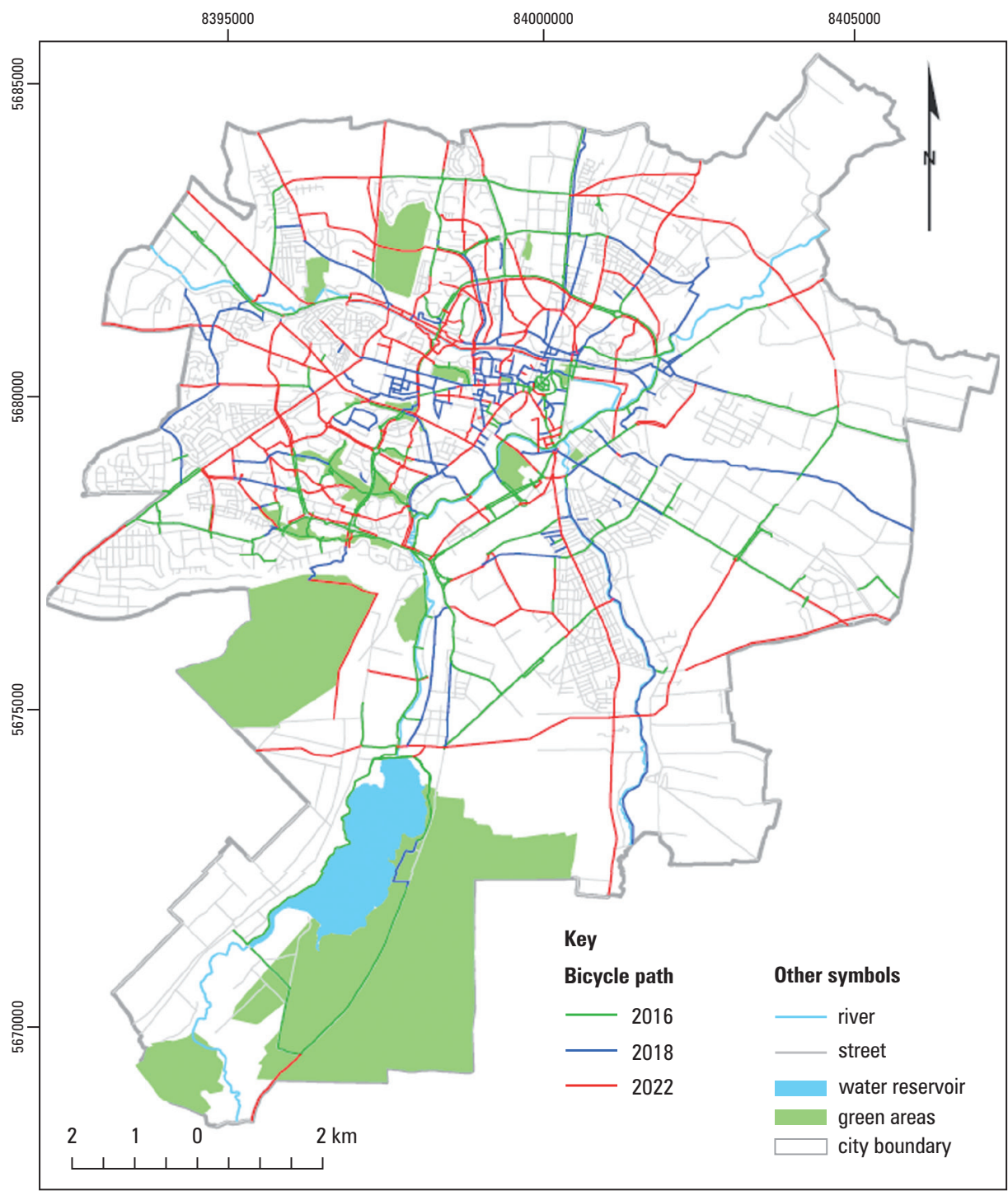

Source: Authors' own study

Fig. 7. Development of biking infrastructure in 2016-2022 (scale 1:90 000) 
Areas with the highest recreational and leisure attractiveness are found in the central part of the city, where the greatest interest in city bike has been recorded. At the same time, only one station was recorded in the Zemborzyce district, where one of the largest recreation and leisure facilities in the city is located, i.e. the Zalew Zemborzycki (Zemborzyce Lagoon). Few LRM stations were also recorded within the Bystrzyca River area (Za Cukrownią and Kalinowszczyzna districts), which is not conducive to using a city bike for recreational, leisure or tourism purposes.

The largest concentration of areas of economic importance in Lublin is found in the Felin, Stare Miasto and Śródmieście districts. There is a Special Economic Zone in the Felin district. Two LRM stations are located in that area. There was no significant correlation between this location and the popularity of city bikes. Within the Old Town (Stare Miasto), there is a paid parking zone as well as numerous office buildings and shopping facilities, including one of the largest shopping malls in the city. Therefore, it is justified to locate new LRM stations in this area.

In the years 2018-2022, a significant development of Lublin's cycling infrastructure is foreseen (Fig. 7). There are plans to build about $150 \mathrm{~km}$ of new bicycle routes, which is a $100 \%$ increase compared to the existing condition in 2016 . There are plans to expand the independent bicycle path network by about $50 \%$ compared to 2018 , and to create almost twice as many new bicycle lanes. The forecast is that the increased length of the bicycle network in Lublin will also increase the coverage of the city with the LRM system from $0.8 \mathrm{~km} / \mathrm{km}^{2}$ to $2.4 \mathrm{~km} / \mathrm{km}^{2}$.

\section{Conclusions}

The development of cycling infrastructure should be associated with the development of the Lublin City Bike system and vice versa. The increase in the number of bicycle stations in the city did not significantly increase the coverage, i.e. the area of the city served by the LRM. It only shortened the travel time between individual stations. City bike stations should be located near public transport with high levels of journeys. For bus stops - they should be located near those stops where there are the largest number of bus and tram lines converge, and not near bus terminals, as before. The city bike system should be located in the immediate vicinity of the recreational and leisure areas, in particular the Zemborzyce Lagoon and along the Bystrzyca river. The creation of additional LRM stations at the ends of the reservoir would enable touring around it on a city bike, which would increase the tourist attractiveness of the reservoir.

The city bike system is increasingly used by working people, therefore, it would be advisable to expand it in areas with high density of service and industrial facilities, where there are large numbers of jobs and at the same time a limited number of parking spaces. It is also advisable to locate urban system stations in areas of cultural and educational significance, e.g. near scientific centres or university campuses. In addition, it is recommended to increase the number of stations in districts with high population density. 


\section{References}

Act 1997. Ustawa 1997. Prawo o ruchu drogowym (t.j. Dz. U. z 1997 r. Nr 98, poz. 602 z późn. zm.).

Brzeziński A., Dobrosielski M., Dybicz T., Jesionkiewicz-Niedzińska K., Rezwow-Mosakowska M., Szagała P., Szymański Ł., Władarek P. 2009a. Studium koncepcyjne systemu roweru publicznego dla m.st. Warszawy. TransEko. Urząd Miasta Stołecznego Warszawy. Biuro Drogownictwa i Komunikacji, Warszawa.

Brzeziński A., Dobrosielski M., Dybicz T., Jesionkiewicz-Niedzińska K., Rezwow-Mosakowska M., Szagała P., Szymański Ł., Szagała P., Władarek P. 2009b. Standardy projektowe i wykonawcze dla systemu rowerowego w m.st. Warszawie (Zarządzenie nr 5523/2010 Prezydenta Miasta Stołecznego Warszawy z dnia 18 listopada 2010 r.).

Cal P. 2015. Poradnik aktywnego rowerzysty. Towarzystwo dla Natury i Człowieka, Lublin.

CROW 1993. Sign up for the bike. Design manual for a cycle-friendly infrastructure. Centre for Research and Contract Standardization in Civil and Traffic Engineering, Holandia. European Commission Green Paper 1996, The citizens' network, Bruksela.

Faliszewska A., Korycka-Skorupa J. 2010. Kartodiagram anamorficzny Dorlinga. Polski Przegląd Kartograficzny, 42 (2), 113-127.

Gawarecki H. 1976. Ulicami Lublina. Wydawnictwo Lubelskie, Lublin.

Hyły M., Kopta T. 2010. Standardy techniczne dla infrastruktury rowerowej Miasta Lublin z 2010 roku (Zarządzenie nr 415/2010 Prezydenta Miasta Lublin z dnia 10 czerwca 2010 r.).

European Commission 2000. Komisja Europejska 2000. Miasta rowerowe miastami przyszłości. Biuro oficjalnych publikacji wspólnot europejskich, Luksemburg. http://bit.ly/2KG9qRg [accessed: 27.04.2019].

Kopta T., Buczyński A., Hyła M., Lustofin B., Obara G., Rolla M. 2012. Konkurencyjność roweru w zakresie czasu podróży. Generalna Dyrekcja Dróg Krajowych i Autostrad. Departament Studiów Warszawa, Wydział Studiów w Krakowie, Zespół ds. Ścieżek (Dróg) Rowerowych, Warszawa-Kraków.

Król K. 2015a. Conception of a touristic map and nature protection forms created with use of open data sources and free software on a Grybów commune example. Geomatics, Landmanagement and Landscape (GLL), 4, 49-59. DOI: 10.15576/GLL/2015.4.49

Król K. 2015b. The description and comparative analysis of chosen tools automatizing the process of creating interactive maps of spatial objects. Geomatics, Landmanagement and Landscape (GLL), 3, 91-99. DOI: 10.15576/GLL/2015.3.91

Król K., Bedla D. 2016. Geoinformacja w sprzedaży produktu turystycznego. Marketing i Rynek, 3, 20-28.

Król K., Prus B. 2018. Application of interactive charts in the evaluation of socio-economic development of regions. The case of Poland. Acta Sci. Pol., ser. Formatio Circumiectus, 17 (3), 141-151. DOI: 10.15576/ASP.FC/2018.17.3.141

Kubicki B. 2015. Analiza rozmieszczenia stacji roweru miejskiego w Lublinie z wykorzystaniem Systemów Informacji Przestrzennej. Praca inżynierska, Uniwersytet Przyrodniczy w Lublinie.

Kwon S., Janz K.F., Letuchy E.M., Burns T.L., Levy S.M. 2015. Active lifestyle in childhood and adolescence prevents obesity development in young adulthood. Obesity, 23 (12), 2462-2469.

LRM 2016. Lubelski Rower Miejski. https://www.lubelskirower.pl [accessed: 27.04.2019]

Meddin R. 2016. The Bike-sharing World - Year End Data 2015. The Bike-sharing Blog. http:// bit.ly/2NfFxJx [accessed: 27.04.2019].

Prus B., Król K., Chrobot K. 2018. Analysis of the correlation between socio-economic development and land prices. A study of the Zagnańsk municipality. Acta Sci. Pol., ser. Formatio Circumiectus, 17 (2), 87-94. DOI: 10.15576/ASP.FC/2018.17.2.87 
Regulation 1999. Rozporządzenie Ministra Transportu i Gospodarki Morskiej z dnia 2 marca 1999 r. w sprawie warunków technicznych, jakim powinny odpowiadać drogi publiczne i ich usytuowanie (Dz. U. z 1999 r. Nr 43, poz. 430 z późn. zm.).

Regulation 2002. Rozporządzenie Ministrów Transportu i Gospodarki Morskiej oraz Spraw Wewnętrznych i Administracji z dnia 31 lipca 2002 r. w sprawie znaków i sygnałów drogowych (Dz. U. z 2002 r. Nr 170, poz. 1393 z późn. zm.).

Regulation 2003. Rozporządzenie Ministra Infrastruktury z dnia 3 lipca 2003 r. w sprawie szczegółowych warunków technicznych dla znaków i sygnałów drogowych oraz urządzeń bezpieczeństwa ruchu drogowego i warunków umieszczenia na drogach (Dz. U. z 2003 r. Nr 220, poz. 2181 z późn. zm.).

Resolution 2011. Uchwała 2011. Polityka Rowerowa Miasta Lublin z 2011 roku (Uchwała nr 224/XIV/2011 Rady Miasta Lublin z dnia 20 października 2011 roku).

Rowerowy Szczecin 2012. Standardy projektowe i wykonawcze systemu rowerowego Miasta Szczecin. Urząd Miasta Szczecin, Szczecin.

Shaheen S.A., Guzman S., Zhang H. 2010. Bikesharing in Europe, the Americas, and Asia: past, present, and future. Transportation Research Record, 2143 (1), 159-167.

Wiącek A., Gorczyca K. 2013. Lublin Rowerem - przewodnik miejskiego rowerzysty 2013. Towarzystwo dla Natury i Człowieka, Lublin.

Wilczyński B. 2018. Wschodni Szlak Rowerowy Green Velo - mocny start i co dalej? Głos w dyskusji na temat dalszego rozwoju sieciowego produktu turystycznego. Biuletyn KPZK PAN, 269, 236-241.

Prof. dr hab. inż. Krzysztof Gawroński

Uniwersytet Rolniczy w Krakowie

Katedra Gospodarki Przestrzennej i Architektury Krajobrazu

ul. Balicka 253c, 30-198 Kraków

e-mail: krzysztof.gawronski@urk.edu.pl

ORCID: https://orcid.org/0000-0002-9922-7373

Dr inż. Karol Król

Uniwersytet Rolniczy w Krakowie

Katedra Gospodarki Przestrzennej i Architektury Krajobrazu

al. Mickiewicza 24/28, 30-059 Kraków

e-mail:k.krol@onet.com.pl

website: http://homeproject.pl

ORCID: https://orcid.org/0000-0003-0534-8471

Dr inż. Grażyna Gawrońska

Uniwersytet Rolniczy w Krakowie

Katedra Melioracji i Kształtowania Środowiska

al. Mickiewicza 24/28, 30-059 Kraków

e-mail: grazyna.gawronska@urk.edu.pl

ORCID: https://orcid.org/0000-0001-8816-1367

Bartosz Kubicki

Uniwersytet Rolniczy w Krakowie

Katedra Gospodarki Przestrzennej i Architektury Krajobrazu

ul. Balicka 253c, 30-198 Kraków 